\title{
GMR
}

\section{Path analysis of the energy density of wood in eucalyptus clones}

\author{
A.M. Couto ${ }^{1}$, P.E. Teodoro ${ }^{2}$ and P.F. Trugilho ${ }^{3}$ \\ ${ }^{1}$ Departamento de Ciência Florestal, \\ Universidade Estadual do Mato Grosso do Sul, Aquidauna, MS, Brasil \\ ${ }^{2}$ Departamento de Biologia Geral, \\ Universidade Federal Viçosa, Viçosa, MG, Brasil \\ ${ }^{3}$ Departamento de Ciência Florestal, \\ Universidade Federal de Lavras, Lavras, MG, Brasil \\ Corresponding author: P.E. Teodoro \\ E-mail: eduteodoro@hotmail.com \\ Genet. Mol. Res. 16 (1): gmr16019536 \\ Received November 16, 2016 \\ Accepted December 19, 2016 \\ Published March 16, 2017 \\ DOI http://dx.doi.org/10.4238/gmr16019536 \\ Copyright $(2017$ The Authors. This is an open-access article distributed under the terms of \\ the Creative Commons Attribution ShareAlike (CC BY-SA) 4.0 License.
}

\begin{abstract}
Path analysis has been used for establishing selection criteria in genetic breeding programs for several crops. However, it has not been used in eucalyptus breeding programs yet. In the present study, we aimed to identify the wood technology traits that could be used as the criteria for direct and indirect selection of eucalyptus genotypes with high energy density of wood. Twenty-four eucalyptus clones were evaluated in a completely randomized design with five replications. The following traits were assessed: basic wood density, total extractives, lignin content, ash content, nitrogen content, carbon content, hydrogen content, sulfur content, oxygen content, higher calorific power, holocellulose, and energy density. After verifying the variability of all evaluated traits among the clones, a two-dimensional correlation network was used to determine the phenotypic patterns among them. The obtained coefficient of determination (0.94) presented a higher magnitude in relation to the effect of the residual variable, and it served as an excellent model for explaining the genetic
\end{abstract}

Genetics and Molecular Research 16 (1): gmr16019536 
effects related to the variations observed in the energy density of wood in all eucalyptus clones. However, for future studies, we recommend evaluating other traits, especially the morphological traits, because of the greater ease in their measurement. Selecting clones with high basic density is the most promising strategy for eucalyptus breeding programs that aim to increase the energy density of wood because of its high heritability and magnitude of the cause-and-effect relationship with this trait.

Key words: Chemical properties; Direct and indirect effect; Indirect selection; Relationship between traits

\section{INTRODUCTION}

One of the greatest known genetic advances in Brazil occurred in the breeding of the genus Eucalyptus (Reis et al., 2011). This genus has inter and intra-specific variability that expresses diverse anatomical, physical, mechanical, and chemical properties of its wood, making it possible to meet the technological requirements of the most diverse segment of the industrial wood production (Botrel et al., 2007). Currently, forest breeding programs seek to select superior genotypes in terms of high wood production, as well as other wood quality indices that allow the production of industrialized products with high technological content and, therefore, of high commercial value (Rodrigues et al., 2008).

Owing to its influence on industrial processes, the energy density of wood is considered as the most important wood quality index. In sectors, such as steel, pulp and paper, and timber, the energy density can significantly contribute to the promotion of process gains and changes in product features (Rodrigues et al., 2008). Therefore, it is essential to understand the genetic influence on the type, shape, and cellular organization of wood in order to select eucalyptus genotypes with higher energy density. Furthermore, in genetic breeding programs, it is fundamental to establish the correlations between the traits related to the wood quality, because when performing the selection based on one trait, changes occur in the other traits of importance correlated with each other. This is because these correlations do not determine the relative importance of the direct and indirect effects of the traits composing the grain yield (Cruz et al., 2012).

Path analysis proposed by Wright (1921) allows a better understanding of the association of different traits by the deployment of the correlation coefficients into the direct and indirect effects on the primary trait (Corrar et al., 2007). Estimates of these effects are obtained by the regression equations with previously standardized variables. However, despite its importance in establishing the selection criteria in breeding programs, path analysis has not been used in eucalyptus breeding to date. Path analysis has been useful for guiding the breeding strategies in several crops with difficult to measure traits, such as the technological traits in cotton (Farias et al., 2016) and sorghum (Lombardi et al., 2015).

Despite its importance in plant breeding, there are no reports in the literature on the use of path analysis in eucalyptus breeding. Thus, the aim of this study was to identify the wood technology traits that could be used as the criteria for the direct and indirect selection of eucalyptus genotypes with high energy density of wood.

Genetics and Molecular Research 16 (1): gmr16019536 


\section{MATERIAL AND METHODS}

In a clonal test, 24 eucalyptus clones were evaluated in Martinho Campos $\left(19^{\circ} 19^{\prime} \mathrm{S}\right.$ and $45^{\circ} 14^{\prime} \mathrm{W}$ ), Minas Gerais, Brazil. This region has an average annual temperature and accumulated annual rainfall of $22^{\circ} \mathrm{C}$ and $1150 \mathrm{~mm}$, respectively. The area of the clonal test was subjected to the subsoiling process and base fertilization with $300 \mathrm{~kg} / \mathrm{ha}$ Gafsa phosphate and complementary fertilization with $170 \mathrm{~kg} / \mathrm{ha}$ NPK formulation 06-30-06. Normal cultivation practices were used for the eucalyptus crop in this region; herbicides were used for weed control and integrated pest management for pest control.

An experimental unit consisted of 10 plants from each clone, and the experiment was conducted in a completely randomized design with five replicates. The following traits were assessed: basic wood density (BD), total extractives (EXT), lignin content (LIG), ash content $(\mathrm{ASH})$, nitrogen content $(\mathrm{N})$, carbon content $(\mathrm{C})$, hydrogen content $(\mathrm{H})$, sulfur content $(\mathrm{S})$, oxygen content $(\mathrm{O})$, higher calorific power $(\mathrm{CP})$, holocellulose (HOL), and energy density (ED).

For verifying the genetic variability among eucalyptus clones, a joint analysis of variance was performed for each trait according to the statistical model described in Equation 1:

$$
Y_{i j}=m+C_{i}+e_{i j}
$$

(Equation 1)

where $Y_{i j}$ is the value observed in the $i$-th clone at $j$-th replicate; $m$ is the overall mean of the fix effect; $\mathrm{C}_{\mathrm{i}}$ is the random effect of the $\mathrm{i}$-th clone; and $\mathrm{e}_{\mathrm{ij}}$ is the random error associated with the $\mathrm{Y}_{\mathrm{ij}}$ value.

Subsequently, for each trait the following parameters were estimated: heritability (Equation 2) and selective accuracy (Equation 3).

$$
\begin{gathered}
\hat{h}^{2}=\frac{\hat{\sigma}_{G}^{2}}{\hat{\sigma}_{F}^{2}} \\
S A=\sqrt{1-\frac{1}{F_{c}}}
\end{gathered}
$$

where $\hat{\sigma}_{G}^{2}$ is the genotypic variance; $\hat{\sigma}_{F}^{2}$ is the phenotypic variance; and $\mathrm{F}_{\mathrm{C}}$ is the calculated value of $\mathrm{F}$. Equation 4:

Phenotypic correlations $\left(\mathrm{r}_{\mathrm{F}}\right)$ between the pairs of traits were estimated according to

$$
r_{F}=\frac{C O V_{F(x y)}}{\sqrt{\hat{\sigma}_{F x}^{2} x \hat{\sigma}_{F y}^{2}}}
$$

where $C O V_{F(x y)}$ is the phenotypic covariance between the traits $\mathrm{X}$ and $\mathrm{Y} ; \hat{\sigma}_{F x}^{2}$ is the phenotypic variance of the trait $\mathrm{X}$; and $\hat{\sigma}_{F y}^{2}$ is the phenotypic variance of the trait $\mathrm{Y}$.

Genetics and Molecular Research 16 (1): gmr16019536 
To graphically express the functional relationship between the estimates of phenotypic correlations between the traits, a correlation network was used, in which the proximity between nodes (traces) was proportional to the absolute value of the correlation between the nodes. The edge thickness was controlled by applying a cut-off value of 0.50 , which meant that only $\left|\mathrm{r}_{\mathrm{F}}\right| \geq$ 0.50 had their edges highlighted. Finally, the positive correlations were highlighted in green, while the negative correlations were represented in red.

Subsequently, the $\mathrm{r}_{\mathrm{F}}$ were deployed by path analysis into direct and indirect effects, considering the model described in Equation 5:

$$
Y=p_{1} X_{1}+p_{2} X_{2}+\ldots+p_{n} X_{n}+p_{\varepsilon} u
$$

where $\mathrm{Y}$ is the principal dependent variable $\mathrm{ED} ; \mathrm{X}_{1}, \mathrm{X}_{2}, \ldots, \mathrm{X}_{\mathrm{n}}$ are the explanatory independent variables; $\mathrm{p}_{1}, \mathrm{p}_{2}, \ldots, \mathrm{p}_{\mathrm{n}}$ are the coefficients of path analysis. The coefficient of determination $\left(\mathrm{R}^{2}\right)$ was calculated by using Equation 7:

$$
R 2=p 1 X 12+p 2 X 22+\ldots 2 p 1 X 1 p 2 X 2
$$

(Equation 6)

The degree of multicollinearity of the $\mathrm{X}^{\prime} \mathrm{X}$ matrix was established based on its number of conditions (NC), which is the ratio between the largest and the smallest matrix eigenvalue (Montgomery and Peck, 2001). If $\mathrm{NC}<100$, the degree of multicollinearity was considered weak, and was not a problem for analysis; if $100 \leq \mathrm{NC} \leq 1000$, the degree of multicollinearity was considered moderate to strong; and if $\mathrm{NC}>1000$, the degree of multicollinearity was considered severe. All statistical analyses were performed with the GENES application (Cruz, 2013).

\section{RESULTS AND DISCUSSION}

Significant differences (F-test) were observed among the eucalyptus clones for all evaluated traits, indicating the existence of a genetic variability among the evaluated materials (Table 1). According to the classification established by Cruz et al. (2012), the estimates of heritability were relatively high $\left(\mathrm{h}^{2}>0.80\right)$ for the traits EXT, LIG, N, S, CP, HOL, and ED. This indicates that these traits might be promising for the selection of eucalyptus clones with higher ED, since this trait has low heritability $\left(h^{2}=0.81\right)$. The estimates of selective accuracy were relatively higher than 0.80 for all traits evaluated. According to the classification established by Resende and Duarte (2007), all traits were evaluated with high selective accuracy (AS > 0.70 ), which indicates the suitability of this database for the proposed study.

As shown in Figure 1, the positive phenotypic correlations were observed between the traits $\mathrm{S} \times \mathrm{N}$ (0.8519), CP x ED (0.5315), ED x EXT (0.5918), BD x EXT (0.5819), and $\mathrm{BD} \times \mathrm{ED}(0.9782)$. The negative phenotypic correlations were observed between the traits $\mathrm{O}$ x C (-0.9700), HOL x LIG (-0.8570), C x S (-0.5534), S x BD (-0.5000), S x ED (-0.5095), EXT x H (-0.6899), CIN x EXT (-0.5142), CIN x BD (-0.5312), CIN x CP (-0.5012), and CIN $x$ ED (-0.5699). Similar results were observed in the other studies, which investigated the association between the traits related to the basic density and physico-chemical properties of wood (Brito and Barrichelo, 1977; Trugilho et al., 2001; Kumar et al., 2010; Protásio et al., 2011; Santos et al., 2011).

Genetics and Molecular Research 16 (1): gmr16019536 
Table 1. Estimates of $P$ value for clone effect, heritability $\left(h^{2}\right)$, and selective accuracy $(\mathrm{SA})$ for the effect of clones and genetic parameters for traits basic wood density (BD), total extractives (EXT), lignin content (LIG), ash content $(\mathrm{ASH})$, nitrogen content $(\mathrm{N})$, carbon content $(\mathrm{C})$, hydrogen content $(\mathrm{H})$, sulfur content $(\mathrm{S})$, oxygen content $(\mathrm{O})$, higher calorific power (CP), holocellulose (HOL), and energy density (ED) assessed in 24 eucalyptus clones.

\begin{tabular}{l|c|c|c|c|c|c|c|c|c|c|c|c}
\hline Parameter & BD & EXT & LIG & ASH & N & C & H & S & O & CP & HOL & ED \\
\hline P value & 0.00 & 0.00 & 0.00 & 0.00 & 0.00 & 0.00 & 0.00 & 0.00 & 0.00 & 0.00 & 0.00 & 0.00 \\
\hline $\mathrm{h}^{2}$ & 0.79 & 0.81 & 0.91 & 0.74 & 0.88 & 0.68 & 0.48 & 0.94 & 0.43 & 0.86 & 0.84 & 0.81 \\
\hline SA & 0.89 & 0.90 & 0.95 & 0.86 & 0.94 & 0.82 & 0.89 & 0.97 & 0.86 & 0.93 & 0.92 & 0.90 \\
\hline
\end{tabular}

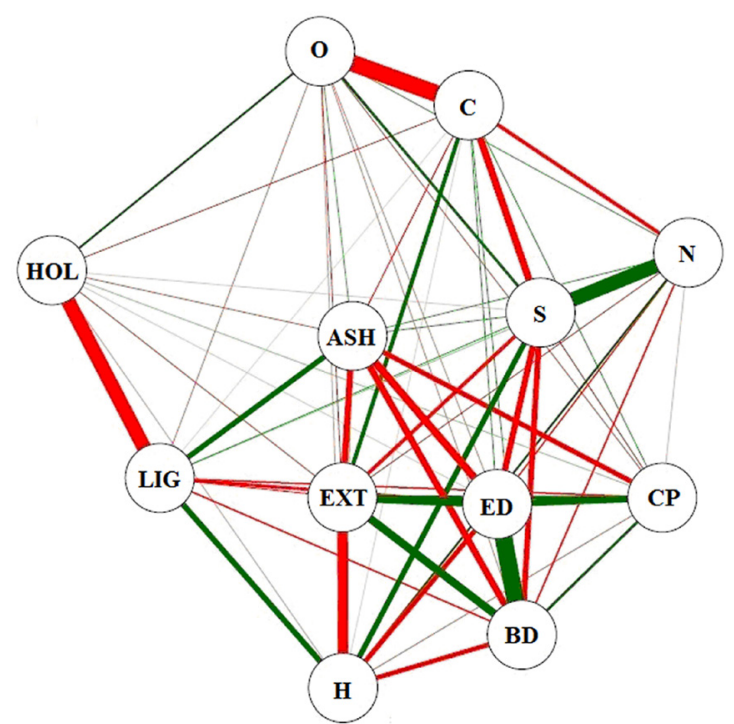

Figure 1. Phenotypic correlation network among the traits basic wood density (BD), total extractives (EXT), lignin content (LIG), ash content (ASH), nitrogen content $(\mathrm{N})$, carbon content $(\mathrm{C})$, hydrogen content $(\mathrm{H})$, sulfur content $(\mathrm{S})$, oxygen content $(\mathrm{O})$, higher calorific power $(\mathrm{CP})$, holocellulose $(\mathrm{HOL})$, and energy density (ED) assessed in 24 eucalyptus clones.

It is important to highlight the importance of using the two-dimensional correlation network to detect complex phenotypic patterns that are difficult to extract with other techniques. The efficiency of this innovative technique has already been demonstrated by previous studies (Ursem et al., 2008; DiLeo et al., 2011; Silva et al., 2016). The main cause of the phenotypic correlation between the two traits was pleiotropism, a property by which a single gene affects more than one trait simultaneously, and linkage disequilibrium, non-random association between alleles of different loci (Mode and Robinson, 1959). Thus, although important, the coefficient of phenotypic correlation might lead to misunderstandings about the relationship between two traits, and might not be a real measure of the cause and effect. A high or low coefficient of correlation between the two traits might be the result of the effect that a third trait or a group of traits has on the pair of traits, not indicating the exact relative importance of the direct and indirect effects of these factors (Cruz et al., 2012).

Therefore, we proceeded to perform the path analysis, which investigated the causeand-effect relationship between the traits. Teodoro et al. (2014) indicated that this analysis provides a detailed knowledge about the influences of the traits involved and justifies the

Genetics and Molecular Research 16 (1): gmr16019536 
existence of the positive and negative correlations of high and low magnitude among the studied traits. However, to obtain the direct and indirect effects of the path analysis, it is necessary that the matrix $X^{\prime} X$ be well conditioned. In the presence of multicollinearity, the variances associated with the estimators of path coefficients can reach excessively high values, making the path analysis unreliable. In addition, the parameter estimates might assume absurd values or display no coherence with the studied biological phenomenon (Cruz et al., 2012). According to the criterion presented by Montgomery and Peck (2001), the matrix of the estimates of the phenotypic correlations showed a severe multicollinearity because the number of conditions was equal to 1231 . Thus, it was necessary to perform the path analysis in crest, by including a constant $\mathrm{K}=0.05$ to the diagonal of the correlation matrix (Table 2).

Table 2. Estimates of the direct and indirect effects of the traits basic wood density (BD), total extractives (EXT), lignin content (LIG), ash content (ASH), nitrogen content $(\mathrm{N})$, carbon content $(\mathrm{C})$, hydrogen content $(\mathrm{H})$, sulfur content $(\mathrm{S})$, oxygen content $(\mathrm{O})$, higher calorific power $(\mathrm{CP})$, holocellulose (HOL), and energy density (ED) evaluated in 24 eucalyptus clones.

\begin{tabular}{l|c|c|c|c|c|c|c|c|c|c|c}
\hline Effect & $\mathrm{BD}$ & $\mathrm{EXT}$ & $\mathrm{LIG}$ & $\mathrm{ASH}$ & $\mathrm{N}$ & $\mathrm{C}$ & $\mathrm{H}$ & $\mathrm{S}$ & $\mathrm{O}$ & $\mathrm{CP}$ & HOL \\
\hline Direct on ED & 0.90 & -0.23 & -0.41 & -0.01 & -0.01 & 0.38 & 0.04 & 0.05 & 0.39 & 0.21 & -0.39 \\
\hline Indirect via BD & - & 0.52 & -0.30 & -0.48 & -0.30 & 0.27 & -0.40 & -0.44 & -0.15 & 0.32 & 0.02 \\
\hline Indirect via EXT & -0.13 & - & 0.07 & 0.12 & 0.06 & -0.10 & 0.16 & 0.09 & 0.07 & -0.09 & 0.05 \\
\hline Indirect via LIG & 0.14 & 0.13 & - & -0.19 & -0.05 & -0.02 & -0.20 & -0.12 & 0.07 & 0.14 & 0.35 \\
\hline Indirect via ASH & 0.00 & 0.00 & 0.00 & - & 0.00 & 0.00 & 0.00 & 0.00 & 0.00 & 0.00 & 0.00 \\
\hline Indirect via N & 0.00 & 0.00 & 0.00 & 0.00 & - & 0.00 & 0.00 & -0.01 & 0.00 & 0.00 & 0.00 \\
\hline Indirect via C & 0.11 & 0.16 & 0.02 & -0.12 & -0.15 & - & -0.02 & -0.21 & -0.37 & 0.11 & -0.11 \\
\hline Indirect via H & -0.02 & -0.03 & 0.02 & 0.01 & 0.02 & 0.00 & - & 0.02 & -0.01 & -0.01 & -0.01 \\
\hline Indirect via S & -0.02 & -0.02 & 0.01 & 0.01 & 0.04 & -0.03 & 0.02 & - & 0.02 & -0.01 & 0.00 \\
\hline Indirect via O & -0.06 & -0.12 & -0.07 & 0.09 & 0.10 & -0.38 & -0.05 & 0.14 & - & -0.08 & 0.13 \\
\hline Indirect via CP & 0.07 & -0.12 & -0.07 & -0.10 & -0.02 & 0.06 & -0.04 & -0.06 & -0.04 & - & 0.03 \\
\hline Indirect via HOL & -0.01 & 0.09 & 0.34 & 0.09 & 0.00 & 0.11 & 0.05 & 0.03 & -0.13 & -0.05 & - \\
\hline Total (correlation) & $0.98^{*}$ & $0.59^{*}$ & -0.39 & $-0.57^{*}$ & -0.33 & 0.30 & -0.45 & -0.51 & -0.16 & 0.53 & 0.08 \\
\hline Coefficient of determination $\left(\mathrm{R}^{2}\right)=0.99$ \\
Effect of the residual variable $=0.06$
\end{tabular}

* Significant by the $t$-test at $5 \%$ probability.

In the genetic breeding of eucalyptus, it is important to identify, among the traits with high correlation with ED, those with the greatest direct effect in favor of selection, such that the correlated response through indirect selection proves to be efficient and provides cost reduction of the programs, since the evaluation of this trait is laborious and expensive. Thus, the $\mathrm{BD}$ trait was found to be the most important trait because it presented the greatest direct effect on the principal dependent variable (ED), indicating the presence of cause and effect. In addition, the relatively high heritability and ease of measurement of BD than the principal dependent variable might allow a greater success with indirect selection in eucalyptus genetic breeding programs.

It is obvious that the BD trait exerts indirect effects on the other evaluated traits; this might lead to confusion in the selection strategies when analyzing only the coefficients of phenotypic correlations between the traits. For example, a significant positive $r_{F}$ was observed between the EXT and ED traits, which, a priori, indicates that the selection of clones with relatively higher extractive content would result in the indirect selection of clones with relatively higher energy density. However, the effect of this correlation is conditioned by the indirect effect of energy density. These results show the importance of the deployment of phenotypic correlations in the direct and indirect effects by path analysis.

Genetics and Molecular Research 16 (1): gmr16019536 
The obtained coefficient of determination (0.99) showed higher magnitude of the effect of the residual variable and demonstrates as an excellent model fit in explaining the genetic effects related to the observed variation in the basic wood density of the evaluated eucalyptus clones. However, for future studies, we recommend the evaluation of other traits, especially the morphological ones, due to the greater ease in their measurement.

\section{Conflicts of interest}

The authors declare no conflict of interest.

\section{ACKNOWLEDGMENTS}

We thank Coordenação de Aperfeiçoamento de Pessoal de Nível Superior (CAPES) and Conselho Nacional de Desenvolvimento Científico e Tecnológico (CNPq) for financial support.

\section{REFERENCES}

Botrel MCG, Silva JRM, Trugilho PF, Silva Rosado SC, et al. (2007). Ganho genético em propriedades físicas e mecânicas de clones de Eucalyptus. Sci. Forum 76: 13-19.

Brito JO and Barrichelo LEG (1977). Correlações entre características físicas e químicas da madeira e a produção de carvão vegetal: I. Densidade e teor de lignina da madeira de eucalipto. Sci. Forum 14: 9-20.

Corrar LJ, Paulo E and Dias Filho JM (2007). Análise multivariada. Atlas, Fipecafi.

Cruz CD (2013). GENES - a software package for analysis in experimental statistics and quantitative genetics. Acta Sci. Agron. 35: 271-276. http://dx.doi.org/10.4025/actasciagron.v35i3.21251

Cruz CD, Carneiro PCS and Regazzi AJ (2012). Modelos biométricos aplicados ao melhoramento genético. 3rd edn. Editora UFV, Viçosa.

Demirbas A (2011). Relationships between lignin contents and heating values of biomass. Energy Convers. Manage. 42 : 183-188. http://dx.doi.org/10.1016/S0196-8904(00)00050-9

DiLeo MV, Strahan GD, den Bakker M and Hoekenga OA (2011). Weighted correlation network analysis (WGCNA) applied to the tomato fruit metabolome. PLoS One 6: e26683. PubMed http://dx.doi.org/10.1371/journal. pone. 0026683

Farias FJC, Carvalho LP, Silva Filho JL and Teodoro PE (2016). Correlations and path analysis among agronomic and technological traits of upland cotton. Genet. Mol. Res. 15: gmr.15038239.

Kumar R, Pandey KK, Chandrashekar N and Mohan S (2010). Effect of tree-age on calorific value and other properties of Eucalyptus hybrid. J. For. Res. 21: 514-516. http://dx.doi.org/10.1007/s11676-010-0108-x

Lombardi GMR, Nunes JAR, Parrella RAC, Teixeira DHL, et al. (2015). Path analysis of agro-industrial traits in sweet sorghum. Genet. Mol. Res. 14: 16392-16402. PubMed http://dx.doi.org/10.4238/2015.December.9.8

Mode CJ and Robinson HF (1959). Pleiotropism and the genetic variance and covariance. Biometrics 15: 518-537. http:// dx.doi.org/10.2307/2527650

Montgomery DC and Peck EA (2001). Introduction to linear regression analysis. John Wiley \& Sons, New York.

Protásio TP, Bufalino L, Tonoli GHD, Couto AM, et al. (2011). Relação entre poder calorífico superior e os componentes elementares e minerais da biomassa vegetal. Pesq. Florest. Bras. 31: 113-122. http://dx.doi.org/10.4336/2011. pfb.31.66.113

Reis CAF, Gonçalves FMA, Rosse LN, Costa RRGF, et al. (2011). Correspondence between performance of Eucalyptus spp trees selected from family and clonal tests. Genet. Mol. Res. 10: 1172-1179. PubMed http://dx.doi.org/10.4238/ vol10-2gmr1078

Resende MDV and Duarte JB (2007). Precisão e controle de qualidade em experimentos de avaliação de cultivares. Pesqui. Agropecu. Trop. 37: 182-194.

Rodrigues EAC, Rosado SCS, Trugilho PF and Santos AM (2008). Seleção de clones de Eucalyptus para as propriedades da madeira avaliadas em árvores no campo. Cerne 14: 147-152.

Genetics and Molecular Research 16 (1): gmr16019536 
Santos RC, Carneiro ACO, Castro AFM, Castro RVO, et al. (2011). Correlações entre os parâmetros de qualidade da madeira e do carvão vegetal de clones de eucalipto. Sci. Forum 39: 221-230.

Silva AR, Rêgo ER, Pessoa AMS and Rêgo MM (2016). Correlation network analysis between phenotypic and genotypic traits of chili pepper. Pesqui. Agropecu. Bras. 51: 372-377. http://dx.doi.org/10.1590/S0100-204X2016000400010

Teodoro PE, Silva CA, Junior., Corrêa CC, Ribeiro LP, et al. (2014). Path analysis and correlation of two genetic classes of maize (Zea mays L.). J. Agron. 13: 23-28. http://dx.doi.org/10.3923/ja.2014.23.28

Trugilho PF, Lima JT, Mori FA and Lino AL (2001). Avaliação de clones de Eucalyptus para produção de carvão vegetal. Cerne 7: 104-114.

Ursem R, Tikunov Y, Bovy A, Berloo R, et al. (2008). A correlation network approach to metabolic data analysis for tomato fruits. Euphytica 161: 181-193. http://dx.doi.org/10.1007/s10681-008-9672-y

Wright S (1921). Correlation and causation. J. Agric. Res. 20: 557-585.

Genetics and Molecular Research 16 (1): gmr16019536 